\title{
NEEDS TO ADOPT PROFESSIONAL ETHICAL STANDARD IN SECRETARIAL PRACTICE IN THE ERA OF ICT FOR OPTIMUM PRODUCTIVITY IN ORGANIZATIONS
}

\author{
Ikelegbe, Samuel \\ Department of Office Technology and Management, \\ Delta State Polytechnic, Ogwashi-uku \\ ikelegbesamuel@yahoo.com
}

\begin{abstract}
The study was designed to determine the need to adopt professional ethical standard in secretarial practice in the era of ICT for optimum productivity in organizations. The population of the study consisted of 182 respondents which is made up of Office Technology and Management lecturers programme and managers of organizations in Asaba metropolis in Delta State. A structured questionnaire which was validated by three experts guided the study. Cronbach Alpha technique was used to establish the reliability of the instrument before it was administered on the respondents. Data collected were analyzed using mean and standard deviation. Z-test was used to test the hypotheses at 0.05 level of significance. A 4 point rating scale was used as a guide for respondents. The boundary real limit was that any item with mean value of 2.50 was regarded as agreed, while any mean item with mean value of less than 2.50 was regarded as disagreed. It was concluded that respondents agreed that there is need to adopt ethical standard for secretarial practice, also that there is the need to be aware of special skills for secretarial practice in the era of ICT for optimum productivity. It was recommended among others that professional secretaries should be abreast with ethical standard and special skills required to excel in the ICT era for optimum productivity in organizations.
\end{abstract}

Key Words: Ethical standard, ICT, professional ethics, office technology and management. 


\section{Introduction}

Secretarial practice in Nigeria has been an important career since the colonial era, predating 1960. According to Ahukannah and Ikelegbe (2013), during that period, English ladies dominated the profession. The departure of the colonial administration in 1960 brought new challenges. Nigerians from then needed to train and fill the vacant secretarial positions. But the colonial administration created a legacy because the new Nigerian administration adopted the career structures which the colonial administration used.

The rapid growth in the industrial sector between 1960 and 1970 created numerous secretarial opportunities. However, training secretaries did not quite exist in Nigeria due to absence of training facilities, so the few qualified individual were sent to the pitman college London to train. Also certification of secretaries was made possible through the Royal Society of Arts, London.

Ahukannah and Ugoji in Ahukannah and Ikelegbe (216) stated that after the civil war 19671970, the Nigerian economy witnessed a more rapid growth with a corresponding increase in the quantity and quality of secretaries needed by the public and private sectors. The educational sector responded by mounting certificate and diploma courses in secretarial studies. Traditionally, a secretary was one who supported an executive by helping to manage their schedules, receive visitors, take minutes of meetings and produce communications and other documents. However, today's secretaries (also known as administrative assistants, office coordinators, executive assistants, office managers etc.) are using computers, the internet, and other advance office technologies to perform vital "information management" functions in the modern office.

The nomenclature for secretarial studies programme is now Office Technology and Management (OTM). The programme came into being in 2004 in response to persistent calls by business educators and employers for a change due to the advent of ICT and the modern office scenario. The aim of OTM program is to produce graduates who should fit properly into the office of any computerized organizations and perform professionally the functions of a secretary which include relating the functions of the office to the whole organization, attending meetings and providing information as may be required, making accurate records of proceedings, filing and retrieving information, taking appropriate action independently when face with challenging secretarial office problems, showing personal qualities and attributes that are conducive and co-exist with the work group (NBTE, 2004).

OTM programme trains students to acquire office skills and with in-depth administrative office need to meet the demands and challenges in the business environment. The programme incorporates course in office application, office technology, business administration, professional career, professional ethics and general studies courses. The design of the OTM programme components appear to be responsive to a global initiative (Okoro in Akwajou and Pwol, 2009).

Ethics, according to Ikelegbe (2018) is synonymous with morality. He added that there is no doubt that ethics should be an important part of business activities. Ethical behavior according to Braimoh (2017) is knowing the difference between right and wrong and consciously choosing to do right. He emphasized that workplace ethics are important especially to the secretarial profession because ethical standard when adhere to, promote 
organization culture based on shared values of integrity, accountability, transparency and respect. In addition, ethical standard enhance teamwork, provide emotional security, protect institutional property and enhance positive public image. Secretaries with good work ethics often possess generally strong character. This means they are self-discipline, pushing themselves to complete work tasks instead of requiring others to intervene. They are also often very honest and trustworthy, as they view these traits as befitting the high quality employees they seek to become. Secretaries are expected to demonstrate strong character in order to distinguish themselves from others (Ikelegbe, 2018).

Agholor and Agholor (2020) stated that the ethics of a secretary are moral principles relating to the job that he/she will be bound by. These requirements are automatically taken on board when one accepts any position as a secretary and one will be expected to uphold them at all times. In the views of Segunda (2019), some of the professional ethics which secretaries must adhere to include confidentiality, honesty, loyalty, reliability, responsibility, work unsupervised, multi-tasking, flexibility, commitment, teamwork, accountability, reliable, strong character exhibition and dedication to the job. This implies that adherence to professional ethics would assist secretaries in the performance of their functions.

The advent of information and communication technology has changed the office activities significantly and enlarged the secretarial profession, as it brought about modernization of the office. Hayes in Mohammed (2016) recounted that advances in information and communication technologies have created a new space with which individuals and organizations can operate. Those individuals and organizations that have learned to take advantage of the opportunities afforded by operating in the new space have realized significantly competitive advantages over those that have ignored the opportunities of ICT environment.

Information and communication technology is defined as the tools, facilities, processes, and equipment that provide the required environment with the physical infrastructure and the services for generation, transmission, processing, storing and dissemination of information in all forms including voice, text, data, graphics and video (Asabere and Enguah in Mohammed, 2016). Therefore, there is no doubt that ICT is playing an important role in the several sectors all over the world. This development included office management where the professional secretary is contributing in the organizations to achieve organizational goals, there is therefore the need for the secretary to adopt professional ethical standard in achieving the secretaries' purposes in the organization.

Professional ethical standard constitute standards or codes of conduct set by people in a specific profession (Braimoh 2017). Members of any profession abhor bad, dishonest or irresponsible behavior from any of their members. This is achieved by setting out expected behaviours in the form of professional ethics, therefore, all professionals must work together or try to uphold a good reputation. The concept of professional ethics according to Braimoh (2017) comprises what a professional should or should not do in the workplace and professionals are expected to uphold professional ethics by not getting involved in any type of conflict of interest.

According to Donaldson and Davis in Braimoh (2017), professional ethics programme in any organization legitimize managerial actions, strengthens the coherence and balance of the organizations culture, improves trust in relationships between individuals, supports greater 
consistency in standards and qualities of product, cultivate greater sensitivity to the impact of the enterprise values and messages. Others are that; ethical programme cultivate strong team work, support employee growth, help avoid criminal act, lend a hand in managing values and serve as an insurance policy, because they help ensure that policies are legal. Therefore, the need to inculcate professional ethical standard in secretarial practice will no doubt enable secretaries contribute optimally to organizations productivities.

\section{Statement of the Problem}

The introduction and application of ICT has brought a revolution and greater effectiveness in day to day working of offices. According to Evans (2015), secretarial profession has come a long way from change in gender dominance (female) to technologies that have improve work output and increased job opportunities, and administrative office roles have also remained an integral part of business operations, and all signs indicated that the secretarial profession is here to stay. However, there are set backs as observed by Agholor and Agholor (2020), that there was no empirical evidence to show that the objectives of the office technology and management curriculum are realized especially with respect to professional ethics and work performance. Also employers of labour have often complained of absence of professionalism in most trained office technology and management graduatesthat, some of those employed have not performed to expectation and are without ethical standard expected from them. The researcher is therefore interested in determining the need to adopt professional ethical standard in secretarial practice in the era of ICT for optimum productivity in organization.

\section{Purpose of the Study}

The purpose of the study was to determine the need to adopt professional ethical standard on secretarial practice. Specifically, the study sought to determine;

1. Ethical standard expected of professional secretaries for practice in the era of ICT for optimum productivity in organizations.

2. Specialized skills required by the professional secretaries for practice in the era of ICT for optimum productivity in organizations.

\section{Research Questions}

The following research questions guided the study;

1. What are the ethical standard expected of professional secretaries for practice in the era of ICT for optimum productivity in organization?

2. What are the specialized skills required of professional secretaries for practice in the era of ICT for optimum productivity in organizations?

\section{Hypotheses}

The following null hypotheses were raised and were tested at 0.05 level of significance;

1. Office technology and management lecturers and managers of organizations do not differ significantly in their mean responses on ethical standard expected of professional secretaries for practice in organizations for optimum productivity in organizations. 
2. Male and female lecturers of OTM and managers in organizations do not differ significantly in their mean responses on specialized skills required of professional secretaries for practice in organizations.

\section{Method}

Descriptive survey research design was adopted for the study. The area of the study is Delta State. The population of the study consisted of lecturers in Office Technology and Management programme from Delta State Polytechnics, Ogwashi-Uku and Otefe-Oghara and managers of organizations that engage the services of professional secretaries in their offices in Asaba metropolis. A total of 182 respondents were involved with the investigation and there was no sampling.

A 44 items structured questionnaire developed by the researcher was the instrument for data collection. The instrument was validated by 3 experts to determine the consistency of the instrument and its ability to answer the research questions. All the suggestions of the experts were incorporated into the final draft of the questionnaire that was used for data collection. Cronbach Alpha technique was used to establish the reliability of the instrument which yielded overall reliability coefficient of 0.88 . This indicated that the instrument was reliable in collecting data used in answering the research questions for the study.

The administration of the instrument was carried out with the help of three research assistants, they were briefed adequately of the purpose for the study. Data collected regarding the study were analyzed using mean and standard deviation while z-test was used to test the null hypotheses at 0.05 level of significance. A four point rating scale with response categories as strongly agreed $(\mathrm{SA})=4$, agreed $(\mathrm{A})=3$, disagreed $(\mathrm{D})=2$ and strongly disagreed $(\mathrm{SD})=1$ were used for the study. Items with mean value of 2.50 and above were considered as agreed while item with mean values below 2.50 were considered disagreed. The benchmark was thus; 3.50-4.00 strongly agreed, 2.50-3.49 agreed, 1.50-2.49 disagreed and 1.00-1.49 strongly disagreed. 


\section{Results}

Research Question 1: What are the ethical standards expected of professional secretaries for practice in the era of ICT for optimum productivity in organizations?

Table 1: Mean and standard deviations of ethical standard expected of professional secretaries for practice in the era of ICT.

\begin{tabular}{cllll}
\hline S/N & Ethical Standard Expected & Mean & SD & Remarks \\
\hline 1. & Regularity at work & 3.84 & 0.48 & Strongly Agreed \\
2. & Punctuality & 3.82 & 0.47 & Strongly Agreed \\
3. & Keeping information private and confidential & 3.88 & 0.44 & Strongly Agreed \\
4. & Dress appropriately & 3.60 & 0.87 & Strongly Agreed \\
\hline 5. & Bring reliable & 3.72 & 0.73 & Strongly Agreed \\
6. & Loyalty to your boss and organization & 3.81 & 0.45 & Strongly Agreed \\
7. & Work unsupervised & 3.68 & 0.56 & Strongly Agreed \\
8. & Completing task as at when due & 3.50 & 0.79 & Strongly Agreed \\
9. & Maintaining cordial relationship with your colleagues & 3.64 & 0.80 & Strongly Agreed \\
10. & Accept mistakes when they occur & 3.64 & 0.69 & Strongly Agreed \\
11. & Avoid shifting blame to colleagues & 3.58 & 0.60 & Strongly Agreed \\
12. & Taking responsibility for actions taken & 3.68 & 0.57 & Strongly Agreed \\
13. & Be cooperative & 3.66 & 0.54 & Strongly Agreed \\
14. & Avoid taking bribe & 3.81 & 0.66 & Strongly Agreed \\
15. & Multi-tasking & 3.75 & 0.61 & Strongly Agreed \\
16. & Be honest & 3.80 & 0.66 & Strongly Agreed \\
17. & Be flexible & 3.75 & 0.44 & Strongly Agreed \\
18. & Good team work abilities & 3.56 & 0.71 & Strongly Agreed \\
19. & Avoid using office time for leisure & 3.51 & 0.69 & Strongly Agreed \\
20. & Avoid gossip & 3.46 & 0.56 & Agreed \\
21. & Being brave in dealing with unforeseen situations & 3.24 & 0.81 & Agreed \\
22. & Commitment to your job & 3.60 & 0.69 & Strongly Agreed \\
23. & Giving adequate information to your boss and & 3.50 & 0.61 & Strongly Agreed \\
& customers when they are required & & & \\
24. & Making superiors, colleagues and visitors cheerfully & 3.60 & 0.67 & Strongly Agreed \\
25. & Having self-control and offering useful suggestions & 3.42 & 0.75 & Agreed \\
& when needed & & & \\
& Grand Mean & $\mathbf{3 . 8 2}$ & $\mathbf{0 . 6 6}$ & Strongly Agreed \\
\hline
\end{tabular}

Source: field research data 2021.

The data in table 1 reveals that respondents rated 22 items as strongly agreed while 3 items were rated agreed. With a grand mean of 3.82, it is concluded that respondents rated items presented on ethical standard of professional secretaries for practice in the era of ICT as strongly agreed. The standard deviation which ranges from 0.44 to 0.81 is an indication that the opinion of respondents is homogenous. 
Research Question 2: What are the specialized skills required of professional secretaries for practice in the era of ICT for optimum productivity in organization?

Table 2: Mean and standard deviation of specialized skills required by professional secretaries for practice in era of ICT.

\begin{tabular}{|c|c|c|c|c|}
\hline $\mathbf{S} / \mathbf{N}$ & Specialized Skills Required & Mean & SD & Remarks \\
\hline 1. & $\begin{array}{l}\text { Knowledge of ICT skills to fit into a computerized } \\
\text { organization }\end{array}$ & 3.65 & 0.56 & Strongly Agreed \\
\hline 2. & $\begin{array}{l}\text { Knowledge of online conference using skype, google } \\
\text { hangout, zoom etc. }\end{array}$ & 3.50 & 0.58 & Strongly Agreed \\
\hline 3. & Ability to organize meeting and take accurate records & 3.00 & 0.75 & Agreed \\
\hline 4. & $\begin{array}{l}\text { Taking appropriate action independently when face } \\
\text { with challenging secretarial office problems }\end{array}$ & 3.25 & 0.65 & Agreed \\
\hline 5. & Knowledge of filing information in filing cabinet & 3.00 & 0.76 & Agreed \\
\hline 6. & $\begin{array}{l}\text { Knowledge of saving and retrieving of information } \\
\text { saved in the computer system }\end{array}$ & 3.80 & 0.42 & Strongly Agreed \\
\hline 7. & Knowledge of job schedule to assign to junior staff & 3.25 & 0.68 & Agreed \\
\hline 8. & Ability to screen incoming telephone calls & 3.00 & 0.79 & Agreed \\
\hline 9. & $\begin{array}{l}\text { Ability to interview visitors coming for visit in the } \\
\text { office }\end{array}$ & 3.25 & 0.76 & Agreed \\
\hline 10. & Ability to manage information without leakages & 3.76 & 0.49 & Strongly Agreed \\
\hline 11. & $\begin{array}{l}\text { Knowledge of materials/equipment required to } \\
\text { accomplish tasks }\end{array}$ & 3.61 & 0.65 & Strongly Agreed \\
\hline 12. & Ability to prepare the boss's itinerary & 3.11 & 0.81 & Agreed \\
\hline 13. & Ability to keeping organizations records & 3.41 & 0.81 & Agreed \\
\hline 14. & Ability to take shorthand dictation & 2.11 & 0.85 & Disagreed \\
\hline 15. & Ability to use stylus keyboard in shorthand writing & 2.08 & 0.91 & Disagreed \\
\hline 16. & Ability to control junior staff & 3.51 & 0.52 & Strongly agreed \\
\hline 17. & $\begin{array}{l}\text { Ability to upload organizational documents on the } \\
\text { cyberspace }\end{array}$ & 2.65 & 0.78 & Agreed \\
\hline 18. & $\begin{array}{l}\text { Ability to access and use information from the } \\
\text { internet }\end{array}$ & 3.40 & 0.66 & Agreed \\
\hline 19. & Ability to perform data analysis with the computer & $\begin{array}{l}3.25 \\
3.03\end{array}$ & 0.60 & $\begin{array}{l}\text { Agreed } \\
\text { Aareed }\end{array}$ \\
\hline
\end{tabular}

Data presented in table 2, indicates that out of the 19 items listed for the study, respondents rated 6 items as strongly agreed, 11 items were rated agreed while 2 items were rated strongly disagreed. With a grand mean of 3.03, it could be concluded that respondents rated research question 2 on specialized skills required by professional secretaries as agreed. The standard deviation which is between 0.42-0.91 indicates that the opinion of respondents is not far apart.

\section{Test of Hypotheses}

Hypothesis 1: Office Technology and Management lecturers and managers of organizations do not differ significantly in their mean responses on ethical standard expected by professional secretaries for practice in organization for optimum productivity in organization. 
Table 3: Summary of z-test analysis of mean differences in the responses of lecturers and managers on the ethical standard expected of professional secretaries.

\begin{tabular}{lcccccccc}
\hline Variable & $\mathrm{N}$ & $\mathrm{X}$ & $\mathrm{S} . \mathrm{D}$ & $\mathrm{Df}$ & $\begin{array}{l}\text { Level of } \\
\text { Significance }\end{array}$ & z-cal & z-crit & Decision \\
\hline OTM lecturers & 42 & 3.17 & 0.78 & & & & \\
& & & & 180 & 0.05 & 0.03 & 1.96 & NS \\
Managers in organization & 140 & 3.20 & 0.64 & & & & \\
\hline
\end{tabular}

Source: field survey data, 2021.

Key: $N=$ no of respondents, $X=$ man, $S D=$ standard deviation, $D f=$ degree of freedom, $z-$ cal $=$ calculated $z$-test value, $z$-crit $=z$ test table value .

The analysis in table 3 shows that the z-test of 0.2 , is less than the z-critical of 1.96 with 180 degree of freedom and 0.05 level of significance. This implies that null hypothesis of no significant difference is accepted. This means that OTM lecturers and managers of organizations do not differ in the mean rating on the ethical standard expected of professional secretaries to practice in organizations in the ICT era for optimum productivity.

Hypothesis 2: Male and female OTM lecturers and managers in organizations do not differ significantly in their mean responses on specialized skills required by professional secretaries for practice in organizations.

Table 4: Summary of z-test analysis of mean differences of male and female respondents on specialized skills required by professional secretaries for practice in organization.

\begin{tabular}{lcccccccc}
\hline Variable & $\mathrm{N}$ & $\mathrm{X}$ & $\mathrm{S} . \mathrm{D}$ & $\mathrm{Df}$ & $\begin{array}{l}\text { Level of } \\
\text { Sig. }\end{array}$ & z-cal & z-crit & Decision \\
\hline Male & 150 & 3.44 & 0.66 & 180 & 0.05 & -0.26 & 1.96 & NS \\
Female & 32 & 3.46 & 0.61 & & & & & \\
\hline
\end{tabular}

Source: Field survey data, 2021.

The result in table 4 indicated that the z-cal of -0.26 is less than the z-critical of 1.96 , with 180 degree of freedom at 0.05 level of significance. This implies that there is no significant difference in the responses of male and female respondents, therefore the null hypotheses was accepted. This means that, respondents do not differ in their responses on the specialized skills required by professional secretaries for practice in organizations in the ICT era for maximum productivity.

\section{Discussion}

Findings of the study revealed that office technology and management lecturers and managers in organizations investigated, agreed that there is the need to adopt professional ethical standard in secretarial practice in the ICT era for optimum productivity in organizations. Respondents answer in research question 1 agreed that, ethical practice such as coming to work regularly, being punctual at work, dressing appropriately, keeping of confidential information, being reliable, loyalty and work unsupervised are necessary. Other ethical standards include maintaining cordial relationship, accepting blame, be cooperative, avoid taking bribe, multi-tasking, honesty, good teamwork, avoid gossiping, avoid using office hours for leisure, be committed to one's duty, being brave in handling issues, providing adequate information when needed, be cheerful in welcoming visitors and having self-control and offering useful suggestions when in a position to do so. 
The findings of this study is in agreement with Olannye and Dickson (2020) who identified golden rules for workplace professionalism to include punctuality and regularity at work, sticking to meeting time, dress appropriately, avoidspending timeon social media, having good customers relation, commitment to the job and accepting faults whenever it happens.

The findings on research question 2 revealed that respondents agreed that specialized skills required of professional secretaries for practice in the era of ICT for optimum productivity in organizations include; knowledge of ICT skills to fit into a computerized organization, knowledge of online conference using Skype, Google hangout, zoom, ability to; organize meetings, take action independently, do filing, save and retrieve document, screen telephone calls, manage information. Others are knowledge of; materials and equipment to keep organizations records. Also ability to control junior staff, upload organization document, access and use information from the internet and ability to perform data analysis with the computer.

The present study agreed with the study of Agholor and Agholor when in a study titled "influence of application of professional ethics on job effectiveness of secretaries in Delta State polytechnics", revealed that professional ethics enhances job effectiveness in supervision, ensuring work schedule, and ensuring all materials to accomplish a task are available. It is also in agreement with Scot in Baba, Ameh and Ezeahurukwe when they stated that professional workplace behavior is necessary for the long term success of business notwithstanding the size of the organization.

\section{Conclusion}

Based on the findings of the study, there is the need to adopt professional ethical standard in secretarial practice, also there is the need to adopt specialized skills for professional secretaries to enhance secretarial practice in this era of ICT for optimum productivity in organization.

\section{Recommendations}

The following recommendations are made based on the findings of the study;

1. Professional secretaries should be abreast with ethical standards required of them in carrying out their duties in order to enhance their productivity optimally.

2. Professional secretaries should learn and master the special skills and the need to deliver tasks as and when due.

3. Secretaries should join their professional bodies, to enable them to beinvolved in their activities in order to have new insight on new areas of training and development.

4. Organizations should endeavor to send their secretaries to further training and secretaries should be sponsored yearly to seminars and conferences for capacity development as this will enhance secretarial activities in performing their functions. 


\section{REFERENCES}

Agholor, S.I. \&Agholor, P.A. (2020). Influence of application of professional ethics on job effectiveness of secretaries in Delta State. Journal of the Association of Business Educators of Nigeria. 7(1), 333-340.

Ahukannah, L.I. \&Ikelegbe, S. (2016). Office careers development in Nigeria. Rupee.com publishers \& coy: Asaba.

Akwajou, U.Z. \&Pwol, J.F. (2009). The millennium secretary and information communication technology. Journal of Emerging Trends in Educational Research and Policy. 4(7), 215-224.

Baba, E.I., Ameh, A.O. \&Ezeahurukwe, N.L. (2020). Professionalism in business education: A panacea for youth unemployment. Conference proceedings of Association of Business Educators of Nigeria (ABEN): 7(1), 555-565.

Braimoh, M.Z. (2017). Professional ethics in the workplace. Safmos publishers: Ibadan.

Evans, N. (2015). Information technology job skills standard. New Jersey: Joss Boss Publication Ltd.

Ikelegbe, S. (2018). Business ethical practice and sustainable national development in Nigeria. Nigeria Journal of Association of Business Educators of Nigeria. 5(2), 316323.

Mohammed, Y.M. (2016). Information and communication technology (ICT): A veritable tool for executing secretarial tasks: International Journal of Research and Review 2129. Access on $15^{\text {th }}$ April, 2021 from www.ijrrjournal.com

NBTE, (2004). Office technology and management programme curriculum and course specification.

Olannye, V.E. \& Dickson, C.M. (2020). Workplace professionalism of office technology and management graduates for career sustainability in modern offices of Nigeria Labour Market. Association of Business Educators of Nigeria (ABEN). Conference proceedings. 7(1), 584-595. 